\title{
ANALYSIS OF THE HATI SUHITA NOVEL BY KHILMA ANIS: RELIGIOUS ASPECTS OF HUMAN RELATIONS WITH SELF
}

\author{
Ilmu Hamimah ${ }^{1}$, Nur Khofifah ${ }^{2}$, Hemas Haryas Harja Susetya ${ }^{3}$ \\ ${ }^{1,2,3}$ Program Studi Pendidikan Bahasa Indonesia \\ Universitas Islam Zainul Hasan Genggong
}

\section{Corresponding Author: ${ }^{1}$ nmuhamimah@gmail.com}

\begin{abstract}
Becoming a perfect human is something that cannot happen in the world. However, being a human being who strives and is determined to be perfect is something that can be achieved with all the conviction of the heart and requests for straightness on the path of Alah SWT. accompanied by self-effort towards true goodness. This can be referred to as the religious dimension of one's self to oneself. Instilling a strong religious character and heart readiness to go to the right path. The power of religious character over oneself can be applied in a variety of circumstances. Like being happy, sad, disappointed, impressed or so on. This situation really proves how much a person uses a religious attitude towards oneself. The following article contains several pieces of religious attitudes towards oneself that can add to our insight into this dimension of attitude.
\end{abstract}

Keyword: Religious attitude, human relationship with oneself

\section{ANALISIS NOVEL HATI SUHITA KARYA KHILMA ANIS: ASPEK RELIGIUS HUBUNGAN MANUSIA DENGAN DIRI SENDIRI}

\begin{abstract}
Abstrak
Menjadi manusia yang sempurna adalah hal yang tidak mungkin terjadi di dunia. Namun, menjadi manusia yang berusaha dan bertekad menuju sempurna adalah hal bisa dicapai dengan segala keyakinan hati dan permohonan kelurusan di jalan Alah SWT. disertai dengan usaha diri menuju kebaikan yang haqiqi. Hal ini dapat disebut sebagai dimensi religius seseorang diri manusia terhadap diri sendiri. Menanamkan sifat keagamaan yang kuat dan kesiapan hati untuk menuju ke jalan yang benar. Kekuatan sifat religius terhadap diri sendiri dapat diaplikasikan dalam berbagai keadaan. Seperti keadaan bahagia, sedih, kecewa, terkesan atau sebagainya. Keadaan tersebut sangatlah membuktikan seberapa besar seseorang menggunakan sikap kereligiusan terhadap diri sendiri. Artikel berikut berisi beberapa penggalan sikap religi terhadap diri sendiri yang mampu menambah wawasan kita terhadap dimensi sikap ini.

Kata kunci: Sikap religi, hubungan manusia dengan diri sendiri
\end{abstract}

\section{PENDAHULUAN}

Karya sastra merupakan hasil cipta seseorang yang memiliki nilai keindahan dengan tujuan untuk dapat dibaca, dinikmati, dan diapresiasi oleh masyarakat. Karya sastra dapat dinikmati dari berbagai kalangan baik anak-anak, dewasa, maupun orang tua. Mengutip Djojosuroto, Romadhon (2015) menyatakan karya sastra adalah refleksi pengarang tentang hidup dan kehidupan yang dipadu dengan daya imajinasi dan kreasi yang didukung oleh pengalaman dan pengalaman atas kehidupan tersebut. Cerita yang tekandung dalam karya sastra dapat berupa gambaran atau renungan kehidupan yang disajikan secara jelas dan mendalam, sehingga banyak dijumpai kisah-kisah yang bertemakan kehidupan dalam bermasyarakat.

Faruk dalam Kurniawan \& Dewi (2020) mengatakan bahwa karya sastra dapat menggambarkan objek dan gerakgerak yang berbeda dari dunia riil, namun dari segi cara strukturasinya atas objek 
dan gerak-geraknya, karya sastra memperlihatkan persamaan dengan cara strukturisasi dunia riil. Secara definitif strukturalisme memberikan perhatian terhadap analisis unsur-unsur karya (Ratna dalam Kurniawan \& Dewi: 2020).

Setiap manusia yang tercipta tentunya memiliki keyakinan masingmasing untuk menjalani kehidupan yang baik. Setiap manusia juga memiliki sikap keagamaan atau religi, baik terhadap penciptanya, semesta, sosial, bahkan kepada diri sendiri. Menjadi manusia yang taat terhadap aturan yang telah ditetapkan bukanlah hal yang sulit jika dilakukannya dengan keikhlasan atau berserah diri. Sikap manusia yang cenderung pada pola pikirnya sendiri tentu tidak akan mendapat pengaruh buruk di kehidupan. Sebab, hal ini sangat menjadi pertimbangan terhadap kehidupan yang dijalani oleh seseorang. Sehingga, dia benar-benar menjadi dirinya tanpa pengaruh dari orang-orang sekitarnya.

Percaya terhadap sesuatu yang ia yakini merupakan suatu reward bagi diri sendiri sebab telah menjadikannya sosok yang percaya diri dan bertanggung jawab atas kepercayaan yang telah ia yakini sebagai pedoman hidup. Hal ini sekaligus sebagai aplikasi tentang ajaran-ajaran dalam kehidupan yang telah diketahui. Adanya penelitian ini sebagai tambahan keilmuan kita sebagai manusia yang berpedoman senantiasa berbuat baik terhadap diri sendiri ataupun kepada orang lain.

Kisah awal sebuah keluarga kecil yang tentunya masih dikelilingi oleh kebahagian jiwa dan hati setelah acara pernikahan tergelar dengan megahnya. Namun, hal yang terjadi berbalik fakta dengan kejadian biasanya. Semua yang diharapkan memang sangat sulit untuk dicapai. Bahkan jiwa yang awalnya teguh dan tangguh, kini bisa dikatakan telah menyusut secara perlahan. Suhita, wanita sholehah idaman Kyai dan Bu Nyai yang menjadi kepercayaan keduanya untuk meneruskan memimpin pesantren sekaligus menjadi menantu tunggal dari putranya.
Kisah yang belum belum tentu bisa dilalui dengan mudahnya oleh setiap insan. Sebab, kejadian ini tidak hanya berjalan sebentar, cukup lama ia rasakan dan tetap dilaluinya dengan ketabahan dan keikhlasan hati sebab rasa hormat dan ta'dzimnya terhadap Bu Nyai dan Kiyai. Keikhlasan dan ketabahan hati tentu muncul dari kepribadian yang taat terhadap sesuatu yang telah ditetapkan. Sebab, yang menjadi tujuan utama dalam hidup adalah taat terhadap perintah Sang Esa.

Bersikap patuh serta taat merupakan kewajiban diri dalam kehidupan. Hal tersebut dapat dikatan sebagai sosok yang taat beragama dan mematuhi ajaran religi yang dianutnya. Beberapa aspek nilai religius diantaranya adalah hubungan manusia dengan diri sendiri. Aspek hubungan inilah yang akan diuraikan dengan mendetail dalam artikel yang telah tersusun ini, dengan mengaitkan beberapa peristiwa yang terdapat pada novel "Hati Suhita" karya Khilma Anis.

Novel ini dipilih karena didasarkan oleh beberapa alasan, yaitu bahwa novel "Hati Suhita" banyak mengandung unsur pembangun iman serta kelapangan dada dalam menjalani lika-liku takdir dari Tuhan. Novel mengandung makna yang sesuai dengan tuntutan ajaran agama Islam melalui cerminkan tokohnya. Perilaku Islam adalah nilai-nilai religius yang melalui peran para tokoh dalam kehidupannya sehari-hari. Selain itu, novel "Hati Suhita" dalam ceritanya juga kental akan ajaran agama Islam sebagai penambah ilmu pengetahuan.

\section{KERANGKA TEORI}

1. Novel

Novel adalah karya sastra yang menyuguhkan sebuah cerita tidak jauh dari realita kehidupan masyarakat. Novel merupakan karangan berbentuk prosa bebas yang memiliki cerita lebih rinci (detail), lebih mendalam, serta pelaku dalam ceritanya lebih dari lima tokoh, dan lebih banyak melibatkan permasalah yang lebih kompleks. Sebagaimana yang 
dikemukakan oleh Mangunwijaya (Nova \& Munir, 2017: 73) bahwa "Kehadiran unsur religius dan keagamaan dalam sastra adalah setua keberadaan sastra itu sendiri. Bahkan, sastra tumbuh dari sesuatu yang bersifat religius. Pada awal mula segala sastra adalah religius".

Novel merupakan cerita panjang yang sengaja dirangkai oleh penulis sebagai karya sastra yang meliputi kehidupan nyata atau khayalan. Novel juga diartikan sebagai suatu karangan berbentuk prosa yang mengandung rangkaian cerita kehidupan seseorang dengan orang lain di sekelilingnya dengan menonjolkan watak dan sifat pelaku (Nurgiyantoro: 2015). Beberapa pengertian novel di atas memberi kesimpulan bahwa novel bukan hanya sekedar karya yang dikarang dengan rekaan, namun dapat diambil juga dari sebuah pengalaman yang dimodivikasi menjadi cerita yang lebih panjang.

\section{Nilai Religi}

Religius adalah konsep keagamaan menyebabkan manusia bersikap sesuai dengan perintah Tuhan-Nya. Karya sastra sebagai ungkapan makna hidup yang tertangkap oleh batin seorang pengarang yang mengandung aspek religius mempunyai peranan penting bagi kehidupan manusia. Seseorang yang bersifat dengan segala nilai kereligiusannya dapat dikatakan sebagai seseorang yang taat terhadap agama. Sebab, beberapa aspek yang telah terlampir dalam nilai religius telah memenuhi kebutuhan hidup seseorang di dunia sekaligus amal perbuatan untuk kehidupan kehidupan di akhirat kelak.

Azyumardi dalam aertikel Mairochma (2015) menyatakan bahwa bagian dasar agama Islam terdiri dari tiga aspek yakni akidah, syariat, dan akhlak yang terstruktur dan tidak dapat dipisahkan. Sehingga, sesuai dengan judul yang terkait bahwa, ketiga aspek yang disebut tentunya ada dalam diri tokoh dalam memerankan sosok muslim dan muslimat yang taat bergama. Hal ini juga menentukan dari segala kejadian atau peristiwa di dunia, tentunya juga berkaitan dengan syariat agama.

\section{METODE PENELITIAN}

Artikel penelitian ini menggunakan metode kualitatif deskriptif. Sebab, yang menjadi tujuan utama dalam penelitian adalah uraian deskripsi mengenai aspek religi tentang hubungan manusia dengan diri sendiri. Sehingga, yang diperlukan adalah bukti data mengenai aspek religi hubungan manusia dengan diri sendiri yang ada pada diri setiap tokoh pada novel Hati Suhita. Kerja penelitian dan analisis masalah harus dinyatakan dengan ukuran yang objetif (Santosa: 2015). Deskripsi kualitatif merupakan suatu penelitian yang dilakukan dengan tidak menggunakan angka-angka, tetapi mengutamakan keadaan penghayatan terhadap interaksi antar konsep yang sedang dikaji secara empiris (Arikunto: 2010). Jenis penelitian ini sangat cocok digunakan dalam kajian sastra.

Menurut Sugiyono dalam Dhita (2018) bahwa metode penelitian kualitatif adalah suatu penelitian yang digunakan untuk meneliti pada objek yang alamiah dimana peneliti adalah sebagai instrumen kunci, teknik pengumpulan data dilakuakan secara gabungan, analisis data bersifat induktif, dan hasil penelitian kualitatif lebih menekankan makna daripada generalisasi. Sesuai dengan apa yang dikutip Novianti dan Munir dari Nazir (2017) desain deskriptif adalah studi untuk menmukan fakta dengan interpretasi yang tepat. Sehingga, desain ini sangat cocok untuk menganalisis novel.

Kutipan di atas merupakan penjelasan yang tentunya bukan hal asing lagi bagi seorang peneliti. Mengedepankan makna daripada uraian yang bersifar general. Sehingga, pemaknaan pada tahap penelitian ini juga dikaitkan dengan kehidupan masyarakat. Tentunya, hal tersebut sebagai pembuktian bahwa hal yang telah dikutip atau disampaikan dalam kutipan data juga terjadi di dalam kehidupan di dunia.

Penelitian deskriptif kualitatif juga bertujuan sebagai pembuktian kepada 
pembaca, bahwa hal yang terkait dapat dibuktikan dengan fakta-fakta yang ada secara sistematis. Sehingga, uraian deskripsi yang ditulis dalam penelitian bersifat asli atau sesuai dengan fakta. Seperti yang ditulis Dhita dalam jurnalnya bahwa tujuan dari penelitian deskriptif ini adalah untuk membuat deskripsi, gambaran atau lukisan secara sistematis, faktual dan akurat mengenai fakta-fakta, sifat-sifat serta hubungan antar fenomena yang diselidiki.

\section{HASIL DAN PEMBAHASAN Sikap Religius}

(Nurgiyantoro, 2015: 446) menyatakan bahwa kehadiran unsur religius dan keagamaan dalam sastra adalah setua keberadaan sastra itu sendiri. Bahkan, sastra tumbuh dari sesuatu yang bersifat religius. Pada awal mula sastra adalah religius. Istilah "religius" membawa konotasi pada makna agama. Religius dan agama memang erat berkaitan, berdampingan bahkan dapat melebur dalam kesatuan, namun sebenarnya keduanya menunjuk pada makna yang berbeda.

Menurut Muhaimin, dkk dalam Fathurrahman (2016), lebih melihat aspek yang di dalam lubuk hati nurani pribadi, sikap personal yang sedikit banyak misteri bagi orang lain, karena menafaskan intimitas jiwa, cita rasa yang mencakup totalitas ke dalam pribadi manusia. Pendapat tersebut sesuai dengan kenyataan bahwa aspek religius bukan hanya menyangkut agama, namun tentang kejiwaan, keyakinan diri juga termasuk di dalamnya. Kemampuan ini juga sangat mampu mengontrol manusia dalam menjalani kehidupan yang lebih bertabiat.

Karya sastra sebagai ungkapan jiwa pengarang mempunyai tugas untuk memberikan andil sebagai pengantar moral dan kehidupan yang ada di bumi. Pengarang yang berhasil membawakan moral dan kehidupan dalam karya sastra adalah religius. Religi adalah kecenderungan rohani manusia, yang berhubungan dengan alam semesta, yang meliputi segala nilai (baik dan buruk), sedangkan religius yang bersifat religi (keagamaan) atau bersangkut-paut dengan religi.

Pernyataan mengenai keagamaan juga disampaikan oleh Fredrick dalam Kartikowati \& Zubaedi (2016), bahwa rasa ketergantungan yang mutlak (Sense of depent) adalah sumber pokok jiwa beragama. Ketergantungan tersebutlah yang menjadikan manusia menjadi sosok yang lemah. Sehingga untuk bangkit dalam kelemahan, manusia melakukan kegiatan beragama sebagai sikap patuh, permohonan atas segala ketidaksanggupannya dalam menjalani keadaan yang ditakdirkan. Keadaan ini patutlah dikatakan sebagai ketergantungan, karena manusia yang mengalami kelemahan pasti akan terus memohon untuk diberi jalan kemudahan oleh sang Maha Kuasa.

Nilai adalah sebuah konsepsi abstrak yang menjadi acuan atau pedoman utama mengenal masalah mendasar dan umum yang sangat penting dan ditinggikan dalam kehidupan suatu masyarakat, bangsa, atau bahkan kemanusiaan. Dalam pandangan islam, kesungguhan teramat penting karena orang-orang yang selalu mengerjakan perintah Tuhannya akan selalu menang dan bagi orang yang dzalim akan ditempatkan ditempat yang hina (QS. Asy Syu"araa: 224-227). Realitas dalam karya sastra dapat dipahamkan pada alamat (ayat) Tuhan, di mana diungkapkan bahwa keindahan sepenuhnya milik Tuhan, baik dari ciptaannya manusia. Semua keindahan menuju pada keimanan kepada Tuhan yang Maha Indah.

Jadi, dapat disimpulkan bahwa nilai religius dalam Islam berpedoman pada AlQuran dan hadist sehingga menghasilkan sesuatu yang lebih indah dan bahwa religius sebagai penuntun manusia kearah yang baik. Sebagaimana yang disampaikan Nurmadiah (2019) bahwa agama akan memelihara manusia dari penyimpangan, kesalahan dan mejauhakannya dari tingkah laku yang negatif. Selain itu alQuran dan hadist mengandung pesan religius yang dapat diambil seorang pembaca. 


\section{Aspek Religius Hubungan Manusia dengan Diri Sendiri}

Hubungan manusia dengan dirinya sendiri disebutkan pula dengan caracaranya di dalam ayat-ayat takwa serta dicontohkan dengan keteladanan Nabi Muhammad. Hubungan manusia dengan hati nurani atau dengan diri sendiri sebagai dimensi takwa yang kedua yang dapat dipelihara dengan jalan menghayati aturan-aturan akhlak dalam berbagai ayat Al-Quran (Ali, 2013: 369). Di antaranya dengan senantiasa berlaku sabar, pemaaf, adil, ikhlas, berani, memegang amanh, mawas diri, dan dapat mengembangkan karakter, sikap, dan sifat yang baik serta berbudi pekerti.

\section{Mengetahui Sikap Religi Hubungan} Manusia pada Diri Sendiri

"Aku menutup jendela. Tidak. Kang Dharma bukan tandingan Rengganis. Aku harus digdaya tanpa aji. Aku harus menaklukkan Mas Birru dengan kelembutan kasih sayangku. Bukan dengan menghadirkan Kang Dharma."

Kutipan di atas merupakan salah satu bagian sikap kecintaan Suhita terhadap diri sendiri, ketaatan terhadap adab yang telah diajarkan Nabi Saw. untuk tetap berbuat sebaik-baiknya terhadap seseorang, terutama untuk kebaikan hati dan diri sendiri. Kecintaan yang diterapkan tentunya menghasilkan kehidupan yang mampu mencapai puncak kebahagian.

Yudhistira yang sabar dan berwatak samudra yang mampu menguasai segala nafsu. Yang mampu menerima segala watak dan kemauan orang lain. Yudhistira yang sangat mencintai istrinya. Bukan mengabaikan dan menyiakan seperti Mas Birru. Meneladani sifat sabar bukanlah hal yang mudah dilakukan, seorang yang sangat sabar bahkan ikhlas dalam menerima segala ketetapan yang telah diturunkan, maka dapat dikatakan bahwa orang tersebut telah mencapai kebahagian yang penuh. Setara dengan ketaatannya terhadap ketetapan-Nya. Seperti kutipan dari terjemahan kitab Tanqihul Qoul yang berbunyi, Nabi Saw. bersabda:
"Sabar sesaat itu lebih baik dari pada dunia dan seisinya."

Dari hadits tersebut kita mampu mengambil hikmah, bahwa kesabaran yang dilakukan, ketaatan dan kepercayaan terhadap diri sendiri untuk senantiasa melakukan kebaikan dan kesabaran adalah yang sangat menguntungkan terhadap diri sendiri. Meski pada dasarnya, kesabaran tidak dapat ditempuh jika telah mencapai batas kemungkinan, namun secara tidak langsung kita yang berlaku sabar akan mendapat kebaikan yang jauh lebih besar dari sesuatu yang kita lakukan. Oleh sebab itu, kutipan kalimat novel mengenai kesabaran sosok Yudhistira yang mampu menguasai segala permasalan, sehingga bisa dijadikan panutan yang tepat bagi kehidupan kekeluargaan ataupun kehidupan kemasyarakatan.

\section{Hal-Hal yang Harus Dihadapi Ketika Mendapat Permasalahan Kehidupan}

"Sehat, Lin?" tanya Kang Dharma

Aku mengangguk. Hampir menangis.

Aku tidak mungkin mengadukan mengadukan kesepianku karena aku sekarang adalah seorang puteri. Seorang puteri harus menghindari watak cula dan culas. Cula itu ucul ala. Culas itu ucul bablas. Aku tidak mungkin menurunkan wibawaku sendiri.

Kutipan diatas mencerminkan karakter teguh yang dapat membunuh karakter negatif yang ada dalam diri. Lapang dan teliti dalam menghadapi situasi bukan hal yang mudah tapi juga tidak sulit jika dapat mengendalikan diri. Menagis adalah hal yang wajar bagi sosok wanita. Karena wanita cenderung lebih perasa.

Meluapkan segala kekesalan dapat dilakukan dengan hal apapun, namun tetap harus berhati-hati agar tidak terjatuh dalam jurang penyesalan dan kekufuran. Seorang wanita harus tetap menjaga harga dirinya, baik ketika mendapat musibah atau kebahagian. Hal ini dikarenakan kodrat wanita itu sendiri, yakni harus tetap berlaku lemah lembut namun tetap 
tegas dan menerima atau qanaah dengan segala qadar Allah Swt.

"Aku harus mengikhlaskannya. Kalau aku ingin memilikinya padahal dia sudah menikah, itu berarti bukan cinta, tapi ambisi. Ambisi akan meranggas ragaku, jiwaku juga. Maka, aku harus legowo." batin Dharma saat melihat fisik Suhita yang jauh lebih kurus dan tirus dari pada pertemuan sebelumnya.

Kutipan diatas mencerminkan diri dan hati yang lapang. Kedua kutipan ini mencerminkan pada sosok penggambaran seseorang yang tahu bagaimana menerima takdir sang kuasa. Memahami batasan, cara bersikap dan menuangkan ujaran memang harus dimiliki seorang manusia. Perbuatan tersebut tidak lain agar menciptakan manusia yang lebih baik dan lebih menghargai sesama.

Ikhlas adalah respect utama yang harus dilakukan saat menerima musibah. Ikhlas bukanlah hal yang mudah, cukup sulit untuk menerapkannya. Bahkan, seseorang yang baik pun belum tentu berlaku ikhlas. Menjadi sosok yang ikhlas harus didasari dengan keimanan dan ketaqwaan dalam hati. Oleh sebab itu, melakukan perbuatan ikhlas harus diterapkan dalam kehidupan sebagai benteng keimanan dan ketaqwaan.

\section{Kiat-Kiat dalam Mengembangkan Sikap Religi dalam Hubungan Manusia dengan Diri-Sendiri}

Aku lekas sembahyang dan mengaji lalu menguatkan kekuatan untuk berlaga di meja makan saat sarapan nanti, di mana abah dan ummik akanmelihat kami sebagai pengantin baru yang mesra dan sumringah.

"Kowe ki rabi, Nduk, tapi niatono mondok lagi." Ini nasihat abahku di awal pernikahan kami."

"Niatono ngabdi nang Yai Hannan. Niatono ngaji neng Bu Nyai Hannan."

"Inggih, Bah."

"Ilmune Kyai Hannan dan Bu Nyai iki uakeh. Kudu iso nitis neng awakmu. Kowe saiki wes puterane." haru.
"Komsentrasi membesarkan sekolah dan pesantren mertuamu. Liyane dipikir karo mlaku." Ini nasihat ibuku.

Sejak saat itu, kuberikan waktuku untuk melayani abah dan ummik. Kuhabiskan waktuku untuk menyerap sebanyak mungkin ilmu. Apalagi setelah kulihat Mas Birru sama sekali tidak dekat dengan kedua orang tuanya.

Percaya bahwa Allah itu ada dimana dan kapanpun untuk membantu umat-Nya yang sedang mengalami kesulitan dan percaya bahwa takdir yang sudah digariskan adalah kehendak-Nya. Kutipan percakapan di atas sebagai bukti bahwa dalam kegagalan menghadapi suatu usaha yang cukup berat, juga memerlukan dukungana dari orang-orang sekitar kita. Hal ini untuk menghindari diri dari sifat putus asa.

Beberapa pesan abah dan ummik Alin semakin meyakinkan dan menguatkan hatinya untuk tetap kuat dan bertahan di titik yang sama dalam menghadapi segala musibah yang terjadi. Pesan tersebut sekaligus menjadikan Alina sosok wanita yang kuat, bahkan jika diterpa angin kencang sekalipun. Begitulah seharusnya wanita-wanita modern saat ini mencontoh. Bukan hanya sekedar mencontoh riasanriasan di luar saja, namun menghiasi isi hati dengan segala kebaikan jauh lebih baik dan lebih mulia. Oleh sebab itu, menciptakan diri menjadi perempuan sholehah itu lebih penting dari segalanya.

\section{SIMPULAN}

Berdasarkan hasil analisis pada novel Hati Suhita karya Khilma Anis dapat disimpulkan bahwa terdapat nilai religius hubungan manusia dengan diri sendiri sesuai perspektif yang diteliti. Terdapat tiga hal yang menjadi focus peneliti dalam penelitian. Pertama, pemahaman nilai religius hubungan manusia dengan diri sendiri, dengan kutipan data yang dapat mengamalkan ajaran island an bersikap sesuai perintah-Nya. Kedua, hal-hal yang harus dihadapi ketika terdapat permasalahan kehidupan. setiap jalan kehidupan pasti ada sepak terjal yang memang harus dilalui sesuai ikhtiar. Dan 
ketiga, kiat-kiat pengembangan sikap religius dalam hubungan manusia dengan diri sendiri. Pengembangan sikap religius sangat perlu untuk diperhatikan, karena masa modern seperti sekarang akan mengikis nilai akhlak yang seharusnya berada dalam ajaran, namun diacuhkan karena yang tertampak ialah keduniawian. Pengembangan sikap religius dapat merubah diri, pengembangan ilmu yang baik, dan tiada sekat pada sang pencipta.

\section{DAFTAR PUSTAKA}

Ali, Mohammad Daud. 2013. Pendidikan Agama Islam. Jakarta: Rajawali Pers.

Kurniawan, Eva Dwi dan Dewi, Septi Riana. 2020. Bencana dalam Novel-novel Indonesia: Telaah Struktural. Jurnal Sastra Indonesia 9(3) 44-50.

Novianti, Nova. Munir, Sirojul. Nilai Religius Dalam Novel Bulan Terbelah Di Langit Amerika Karya Hanum Salsabiela Dan Rangga Almahendra. Jurnal Literasi. Vol.01 No 02 Oktober 2017.

Nurgiyantoro, Burhan. 2015. Teori Pengkajian Fiksi. Yogyakarta: Gajah Mada University Press.

Nurmadiah. 2019. Manusia dan Agama (Konsep Manusia dan Agama dalam Al-quran). Artikel Agama. Jurnal Pendais Volume 1 Nomor 1.

Prasanti, Dhita. Penggunaan Media Komunikasi Bagi Remaja Perempuan dalam Pencaria Informasi Kesehatan. Jurnal Lontar Vol. 6 No 1 Januari-Juni 2018, 13-21

Romadhon. 2015. Perilaku Tokoh Utama Novel Saksi Mata Karya Suparto Brata : Kajian Psikologi Sastra. Jurnal Sastra Indonesia 4(1) (2015)
Anis, Khilma. 2019. Hati Suhita. Yogyakarta: Telaga Aksara.

Arikunto, Suharsimi. 2010. Prosedur Penelitian Suatu Pendekatan Praktik. Yogyakarta: Rineka Cipta.

Fathurrahman, M. 2016. Pengembangan Budaya Religius Dalam Meningkatkan Mutu Pendidikan. Jurnal Ta'allum, Vol. 04, No. 01, Juni 2016

Kartikowati, Endang. Zubaedi. 2016. Psikologi Agama dan Psikologi Islam Sebuah Komparasi. Jakarta: PT Kharisma Putra Utama.

Santosa, Puji. 2015. Metodologi Penelitian Sastra. Yogyakarta: Azzagrafika.

Syukri, Y.T. 2006. Terjemah Tanqihul Qoul. Surabaya: Penerbit Al-Hidayah. 